\title{
Efficient Synthesis of New Fluorinated Building Blocks by means of Hydroformylation
}

\author{
Lidia Fanfonia ${ }^{a}$ Lisa Diaba ${ }^{a}$ Tomas Smejkal ${ }^{\star b}$, and Bernhard Breit ${ }^{\star a}$
}

\begin{abstract}
Hydroformylation of fluorinated alkenes is an efficient method for the preparation of fluorinated functionalized building blocks for the synthesis of biologically active target structures. In this article we summarize known hydroformylation reactions of fluorinated olefins and we add new results from our research groups. Particular attention is paid to the remarkable influence of organofluorine substituents on catalyst activity, regioand stereoselectivity of the hydroformylation reaction.
\end{abstract}

Keywords: Aldehydes · Alkenes · Hydroformylation · Organofluorides · Rhodium

\section{Introduction}

Fluorine is a key element commonly used in modern pharma and agrochemical products. As a result of the unique electronic and steric properties, fluorinated substituents can beneficially influence the physico-chemical properties, improve biological activity and modulate metabolism of active ingredients. ${ }^{11]}$ Therefore, new technologies which allow the selective and cost-efficient synthesis of various fluorinated intermediates are highly desirable. During the last few years, particularly the toolbox of transition metal-catalyzed reactions for late stage introduction of a single fluorine atom or small fluorinated moieties $\left(-\mathrm{CF}_{3},-\mathrm{CF}_{2} \mathrm{H},-\mathrm{SCF}_{3}, \ldots\right)$ has been expanding rapidly. ${ }^{[2]}$

An alternative strategy exploits derivatization of fluorine-containing substrates. ${ }^{[3]}$ In this context we became interested in transition metal-catalyzed reactions of fluorinated olefins which are readily available starting materials (large amounts of fluorinated monomers are utilized by the polymer industry).

One prominent example of this approach is the elegant synthesis of the herbicide Prosulfuron using 3,3,3-trifluoropropene in a one-pot reaction sequence of a palladium-catalyzed Heck reaction followed by hydrogenation (Scheme 1). ${ }^{[4]}$

${ }^{*}$ Correspondence: Prof. Dr. B. Breita, Dr. T. Smejkal alnstitut für Organische Chemie

Albert-Ludwigs-Universität Freiburg

Albertstrasse 21, 79104 Freiburg i. Bg., Germany

E-mail: bernhard.breit@chemie.uni-freiburg.de

bSyngenta Crop Protection Münchwilen AG

Schaffhauserstrasse, $\mathrm{CH}-4332$ Stein, Switzerland

E-mail: tomas.smejkal@syngenta.com

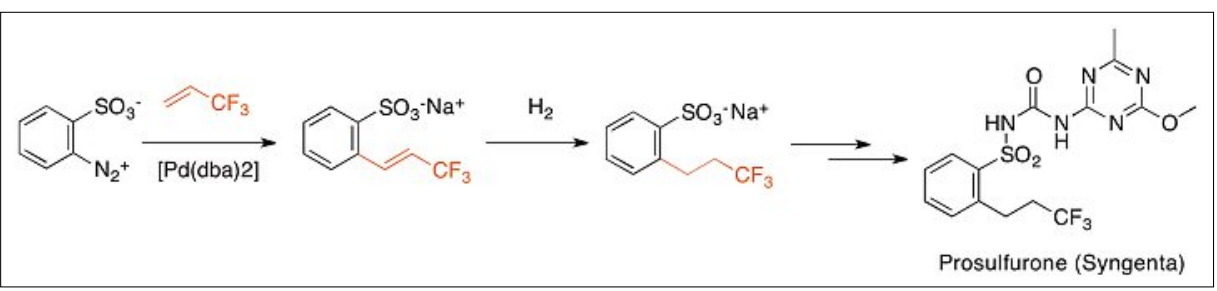

Scheme 1. Efficient synthesis of the herbicide Prosulfurone.

Hydroformylation is a relatively underutilized reaction regarding the use of fluorinated olefins so far. This is surprising considering the fact that it could potentially provide synthetically highly versatile intermediates - fluorinated aldehydes. Moreover, hydroformylation is an example of a particularly atom-economic catalytic reaction, which is well established for the synthesis of bulk chemicals on a multiton scale. ${ }^{[5]}$

The aim of this article is to summarize known hydroformylations of fluorinated alkenes. Particular attention is paid to the remarkable influence of organofluorine substituents on catalyst activity, regio- and stereoselectivity - all factors which are decisive for possible industrial applications. Some new results from our groups are discussed as well.[6]

Table 1. Results of hydroformylation of vinylfluoride.

\begin{tabular}{|c|l|c|c|c|c|c|} 
Entry & \multicolumn{1}{|c|}{ Cat. } & $\mathbf{C O} / \mathbf{H}_{2}[\mathbf{a t m}]$ & Substr/Metal & $\mathbf{T}\left[{ }^{\circ} \mathbf{C}\right]$ & $\mathbf{1 / b}$ & $\begin{array}{c}\text { yield }^{\mathbf{a}} \\
{[\%]}\end{array}$ \\
\hline $\mathbf{1}$ & $\mathrm{Rh}_{4}(\mathrm{CO})_{12}$ & 68 & 2000 & 80 & $0 / 100$ & 81 \\
\hline $\mathbf{2}$ & $\mathrm{HRh}(\mathrm{CO})\left(\mathrm{PPh}_{3}\right)_{3}$ & 68 & 500 & 80 & $0 / 100$ & 52 \\
\hline $\mathbf{3}$ & $\mathrm{Ru}_{3}(\mathrm{CO})_{12}$ & 68 & 100 & 80 & $0 / 100$ & 46 \\
\hline $\mathbf{4}$ & $\mathrm{Co}_{2}(\mathrm{CO})_{8}$ & 110 & 100 & 100 & $0 / 100$ & 30 \\
\hline
\end{tabular}

Conditions: vinyl fluoride $20 \mathrm{mmol}$, toluene, $18 \mathrm{~h}$. aisolated product after distillation

\section{Substrates Fluorinated at the Double Bond}

\subsection{Vinyl Fluoride}

The hydroformylation of vinyl fluoride (VF) was studied by Ojima and found to furnish 2-fluoropropanal (2-FPA) exclusively irrespective of the catalyst applied (see Scheme 2, Table 1). [7] The high regioselectivity for the branched aldehyde is most likely caused by the electronegative fluorine substituent which stabilizes the

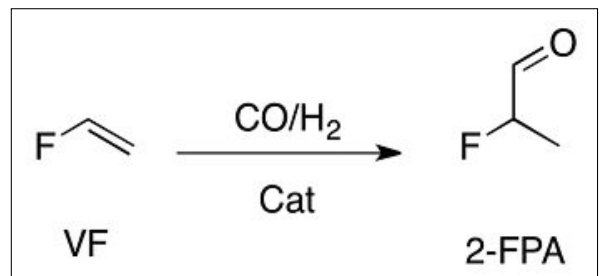

Scheme 2. Regioselective hydroformylation of vinyl fluoride. 
adjacent rhodium-carbon bond formed during the alkene hydrometalation step.

\subsection{1,1-Difluoroethene}

The first and only evidence of a successful hydroformylation applying 1,1-difluorothene as the substrate dates back to a German patent from Hoechst in 1953. ${ }^{[8]}$ With $\mathrm{Co}_{2}(\mathrm{CO})_{8}$ as the precatalyst under harsh reaction conditions (180 atm of syngas and $120-140{ }^{\circ} \mathrm{C}$ reaction temperature) the main reaction product observed was 3,3-difluoro-1-propanol which is formed through hydrogenation of the corresponding aldehyde, with a conversion of $49 \%$ (Scheme 3 ). The aldehyde hydrate of 3,3-difluoropropanal was found as a byproduct.

Since rhodium catalysts show an intrinsic higher activity and chemoselectivity in the hydroformylation of olefins we speculated that it should be possible to develop a hydroformylation of 1,1-difluoroethylene under milder reaction conditions (Scheme 4).

However, after screening of a large number of rhodium complexes together with a series of monodentate and bidentate ligands with different steric and electronic properties as well as exploiting a range of reaction conditions only very low hydroformylation activity was observed. Notably, the best result in terms of conversion and regioselectivity was obtained applying the electron-rich para-anisylphosphine ligand. With this catalyst system and the conditions indicated in Scheme 5 the hydrate of the linear aldehyde was obtained $(10 \%$ conversion, TOF $=0.22 \mathrm{~h}^{-1}, \mathrm{TON}=5.2$ ).

In order to understand why the hydroformylation of this particular substrate is so difficult we performed high level $a b$ initio calculations (CCSD(T)/aug-ccpwCVD(Q)Z//BP86/aug-cc-pVTZ) of the rate and selectivity determining energetic span of the hydroformylation reaction. [9] For triarylphosphine-modified rhodium catalysts this is the energy difference starting from the catalyst resting state, the rhodium-dicarbonyl hydrido diphosphine complex to the transition state of the hydrometalation step. Hence the energetic span for ethylene as well as for 1,1-difluoroethylene were calculated and compared (Fig. 1).

Indeed, it was found that the $\Delta \Delta \mathrm{G}^{\mathrm{TS}}$ for these two substrates is $4.74 \mathrm{kcal} / \mathrm{mol}$. In other words, the hydroformylation of 1,1-difluoroethene is 10000 times slower than that of ethylene. Presumably, the presence of a ligand able to raise the electronic density at the metal might lower the energy of this transition state facilitating the reaction.

\subsection{1,1,2,2-Tetrafluoroethene}

A cobalt-catalyzed hydroformylation

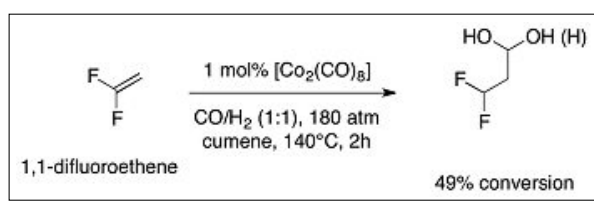

Scheme 3. Cobalt-catalyzed hydroformylation of 1,1-difluoroethene.

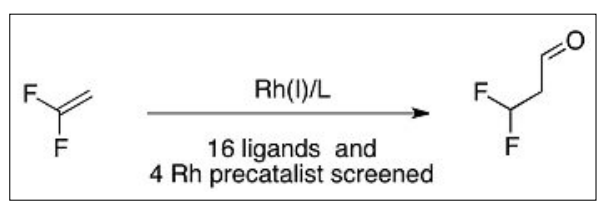

Scheme 4. Rhodium-catalyzed hydroformylation of 1,1-difluoroethene.

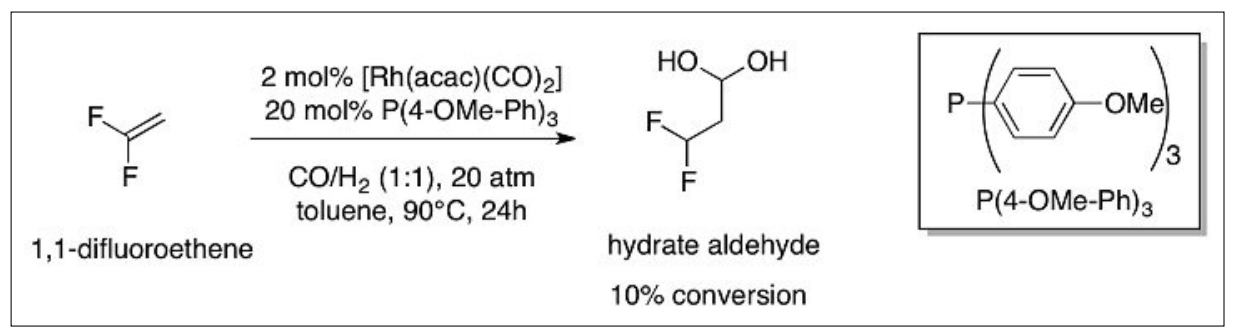

Scheme 5. Best rhodium catalyst for hydroformylation of 1,1-difluoroethene.

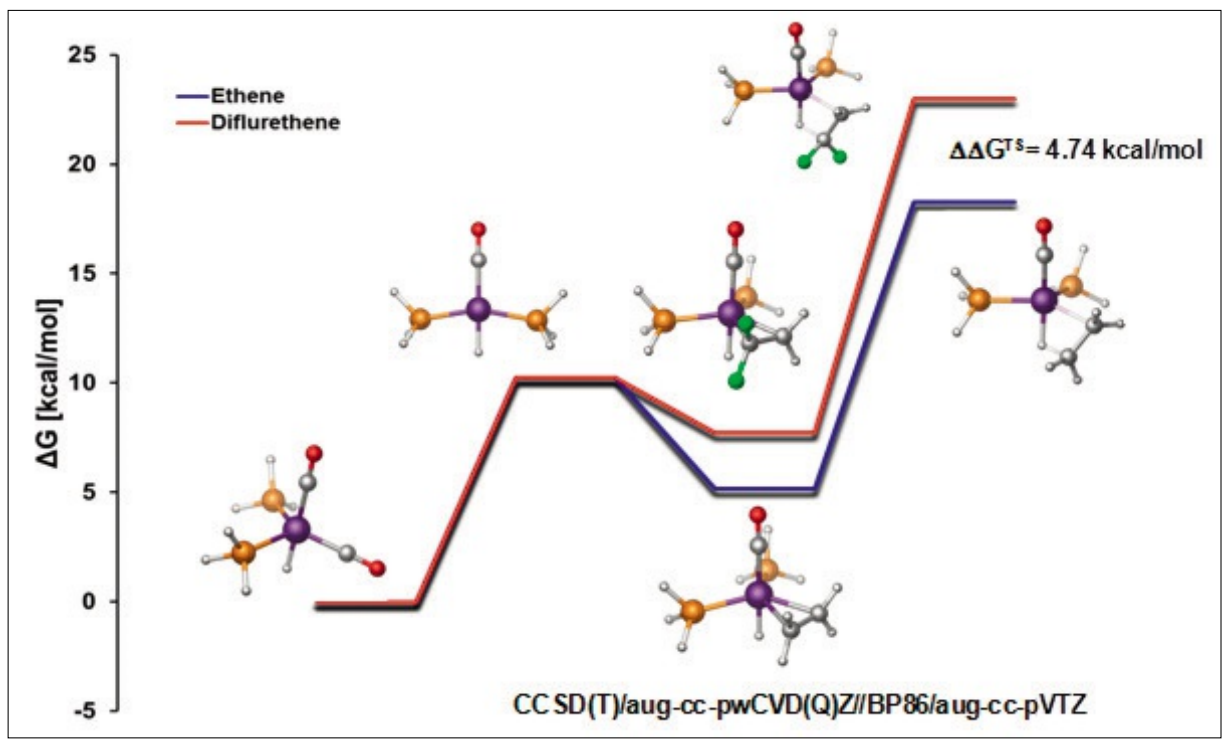

Fig. 1. Comparison between the energy of the transition states in ethylene and 1,1-difluoroethene hydroformylation considering rhodium catalyst bearing $\mathrm{PPh}_{3}$ as modifying ligand (phenyl substituents omitted for clarity).

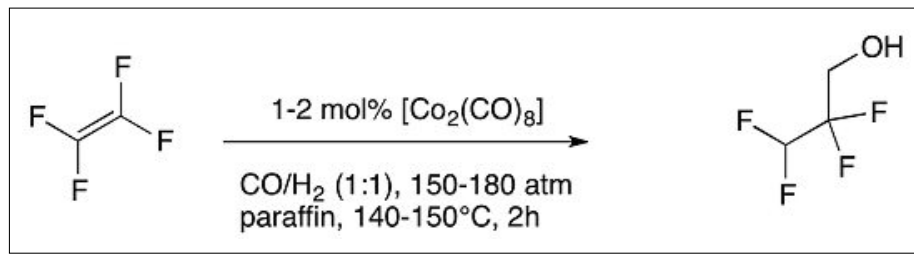

Scheme 6.

Hydroformylation of tetrafluoroethylene.

of tetrafluoroethylene has been reported to occur under harsh reaction conditions (Scheme 6). Also here the product is the alcohol which is derived from a subsequent hydrogenation of the corresponding aldehyde. ${ }^{8]}$ However, the isolated yield was low $(7 \%)$.

\section{Substrate Fluorinated alpha to the Double Bond}

\subsection{3,3,3-Trifluoropropene (TFP)}

The hydroformylation of TFP was first studied by Ojima et al. ${ }^{[7]}$ Interestingly, a re- markable dependence of the regioselectivity of this hydroformylation on the nature of the catalyst was found. While rhodium catalysts furnished the branched aldehyde selectively, using dicobalt octacarbonyl a regioselectivity switch in favor of the linear aldehyde was noted. With a chiral plat-

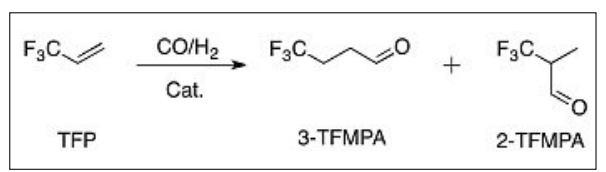

Scheme 7. Hydroformylation of 3,3,3-trifluoropropene. 
inum catalyst the branched aldehyde was obtained in good enantioselectivity ( $e e>$ $90 \%$ ). However, the regioselectivity was rather low (Scheme 7). ${ }^{[10]}$

Building on these earlier experiments with the goal to identify more active and selective catalysts we screened a series of different precatalysts and ligands in the hydroformylation of TFP (Table 2). Our self-assembling 6-diphenylphosphinopyridone ligand (6-DPPon) ${ }^{[11]}$ together with $\mathrm{Rh}(\mathrm{CO})_{2}$ acac furnished an extremely competent catalyst (entry 1). This complex delivered the branched aldehyde with nearly perfect regioselectivity in excellent yield. In addition, conditions much milder $\left(70{ }^{\circ} \mathrm{C}, 20\right.$ bar) and very low catalyst loadings could be used. Interestingly, when we modified the platinum system with Xantphos ligand (entry 3) high regioselectivity in favour of the linear aldehyde was noted.

All fluoro-aldehydes obtained in the hydroformylation of TFP, described above, may serve as excellent intermediates for the synthesis of fluoro-amino acids ${ }^{[12]}$ and various other useful heterocycles such as substituted 2-aminothiophene-3-carboxylate $(\mathbf{1} \text { in Scheme } 8)^{[13]}$ or 2-aminothiazole derivatives (2, 3 and 4 in Scheme 8). [14]

Considering the strong regio-directing effect of an olefinic trifluoromethyl substituent in the rhodium-catalyzed hydroformylation, 1,1-disubstituted olefins (Scheme 9) represent an interesting regioselectivity problem. Further, if a chiral ligand were used, both reaction pathways could provide an asymmetric access to valuable trifluoromethylated aldehyde building blocks.

In general, the formation of linear products from 1,1-disubstituted olefins should be favored for steric reasons (Keulemans' rule). ${ }^{[5 b, 15]}$ On the other hand, the Buchwald group has shown that this effect may be overcome if $\mathrm{R}$ is another regio-directing substituent such as $\mathrm{R}=$ OAc (Scheme 10).

\subsection{3,3,3-Trifluoroprop-1-en-2-yl acetate ${ }^{[16]}$}

Employing a rhodium(I) catalyst in the presence of the chiral phosphine ligands 3,3,3-trifluoroprop-1-en-2-yl acetate could be hydroformylated with good regio- and enantioselectivity. Among the different chiral ligands screened, DuanPhos provided the best results for branched aldehyde in terms of regioselectivity and enantioselectivity.

\section{$3.3 \alpha-C_{3}-S t y r e n e-t y p e$ Substrates}

First we decided to study the regioselectivity of hydroformylation of a variety of $\alpha-\mathrm{CF}_{3}$ styrene substrates by screening a series of different phosphine ligands with $\mathrm{Rh}(\mathrm{acac})(\mathrm{CO})_{2}$ as the precatalyst (Scheme 11 , Table 3 ). The best results are summarized in Table 3 .

Table 2. Effect of different precatalysts and ligands in the hydroformylation of TFP.
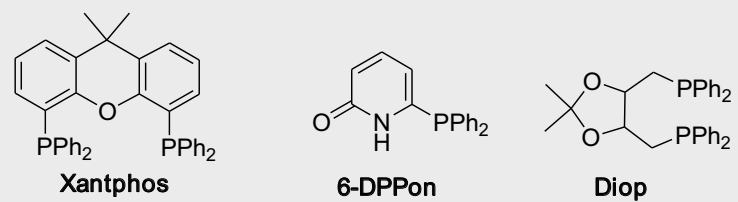

\section{Entry Catalyst}

$\mathrm{CO} / \mathrm{H}_{2}$ Substr/Metal $\mathrm{T}\left[{ }^{\circ} \mathrm{C}\right]$ [bar]

$1 \mathrm{Rh}(\mathrm{CO})_{2} \mathrm{acac} / 6-\mathrm{DPPon}$

20

1000

70

time

$\mathbf{l} / \mathbf{b}^{\mathbf{a}}$

$2^{\mathbf{b}} \quad \mathrm{Rh}_{6}(\mathrm{CO})_{16} / \mathrm{PPh}_{3}$

110

1200

80

24

$5 / 95$

$3 \mathrm{PtCl}_{2}$ (Xantphos) $/ \mathrm{SnCl}_{2}$

96

100

80

20

$3 / 97$

$4^{\text {b }} \quad \mathrm{PtCl}_{2}$ (diop) $/ \mathrm{SnCl}_{2}$

130

100

80

48

$96 / 4$

$5 \quad \mathrm{Co}_{2}(\mathrm{CO})_{8}$

100

100

$71 / 29$

6 $^{\mathbf{b}} \quad \mathrm{Co}_{2}(\mathrm{CO})_{8}$

130

50

100

$96 / 4$

$93 / 7$

Conditions: ligands $10 \%$, toluene. Conversion > 90\%. adetermined by HRGC. ${ }^{\text {bref. [7]. }}$

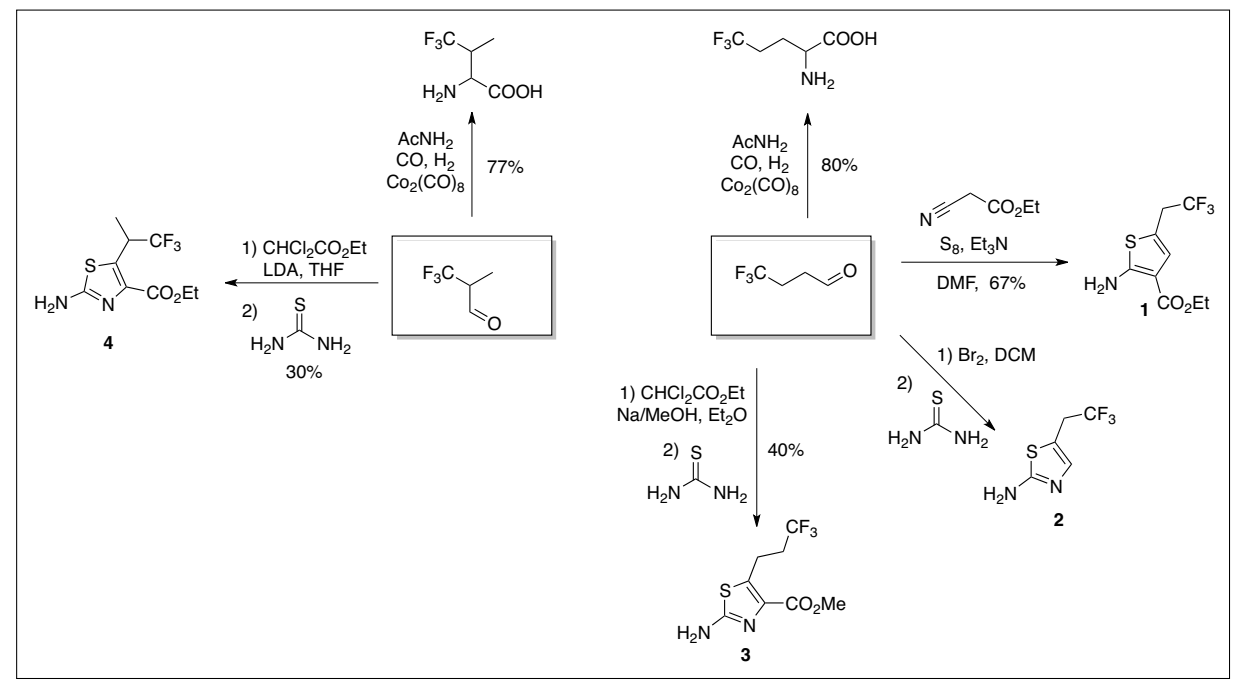

Scheme 8. Transformation of fluorinated aldehydes to amino acids and hetereocycles.

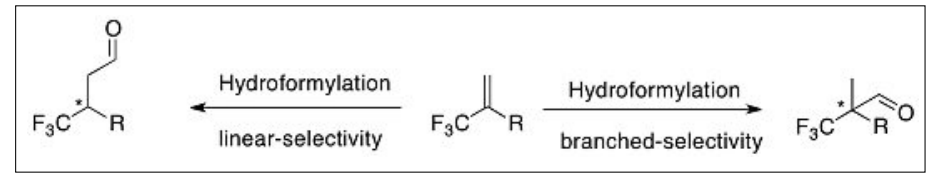

Scheme 9. Hydroformylation of 2-substituted 3,3,3-trifluoropropenes.

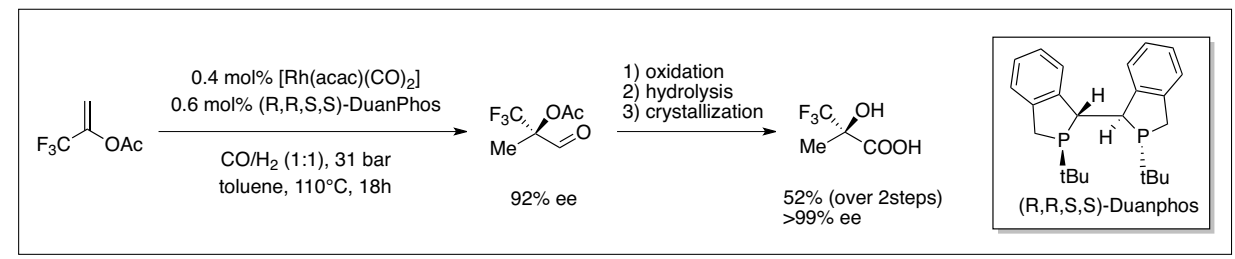

Scheme 10. Enantioselective hydroformylation of 3,3,3-trifluoropropenyl acetate.

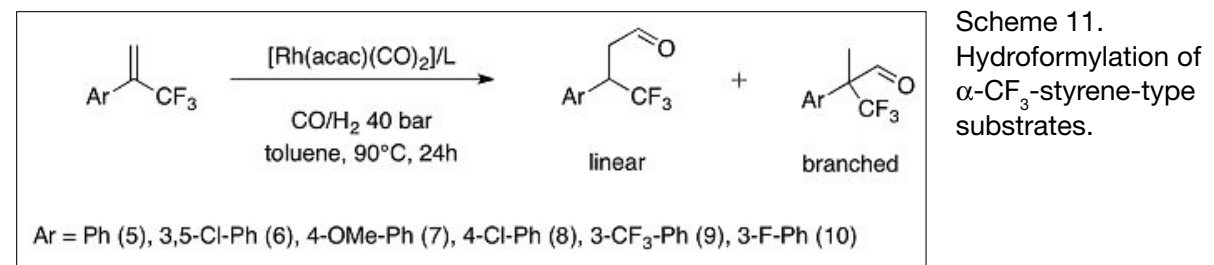

Regioselectivities were in general high for the linear aldehyde when Xantphos was chosen as the rhodium ligand. In contrast, monodentate triphenylphosphine afforded low regioselectivities for most substrates. Only the 3,5-dichlorophenyl substrate 6 
gave high regioselectivity in favor of the branched aldehyde. Accordingly, it is now possible to produce both aldehydes starting from 6 in a regiocomplementary manner (Table 3, entries 2 and 3). Encouraged by the results obtained, an asymmetric version of the reaction was investigated for this substrate. From a screening of 21 commercially available chiral ligands $(R, R)$-Ph-BPE turned out to be best both in terms of conversion, regio- and enantioselectivity (Scheme 12).

\section{4 (E)-4,4,4-Trifluorobut-2-en-1-ol}

$\alpha$-Trifluoromethyl- $\gamma$-butyrolactones are particularly interesting building blocks for the synthesis of compounds having biological ${ }^{[17]}$ activity and for material ${ }^{[18]}$ applications. Several reports have described the synthesis of 2-(trifluoromethyl)butyrolactone (12), ${ }^{[19]}$ but all of these required multiple steps or afforded the product in low yield. Here we report an efficient twostep preparation of $\mathbf{1 2}$ starting from the $\mathrm{CF}_{3}$-substituted allylic alcohol (Scheme 13). Hence, a completely regioselective hydroformylation furnished the lactol $\mathbf{1 1}$. A subsequent oxidation furnished lactone 12 in a high overall yield.

\section{5 (E)-Ethyl-4,4,4-trifluorobut-2- enoate}

$\operatorname{In}(E)$-ethyl-4,4,4-trifluorobut-2-enoate two electron-withdrawing groups $\left(\mathrm{CF}_{3}\right.$ and ester) compete to direct the aldehyde installation in the direct neighbourhood. Interestingly and unexpectedly, good regioselectivity for the 2-position was found employing a rhodium(I)/Biphephos catalyst to furnish aldehyde $\mathbf{1 3}$ which exists preferentially in its enolic form stabilized by the intramolecular hydrogen bond ${ }^{[20]}$ (Scheme 14). This result suggests that an ester group has a stronger directing effect than a $\mathrm{CF}_{3}$ substituent for the rhodiumcatalyzed hydroformylation.

\section{Conclusion and Outlook}

It is well recognized that the introduction of fluorine into organic substrates often brings about unique properties in biology. The same is true for the reactivity of fluorinated substrates in transition-metal catalysis. In this article we have illustrated, how the replacement of $\mathrm{H}$ with $\mathrm{F}$ in a close distance to the reaction site influences both the regio- and stereoselectivity of hydroformylation reactions and how this effect may be used for the selective preparation of fluorinated compounds. In the future we expect to see more applications of hydroformylation in the synthesis of enantiopure fluorinated building blocks and as a key synthetic step toward more complex molecular targets.
Table 3. Results of hydroformylation of $\alpha-\mathrm{CF}_{3}$-styrene-type substrates.

\begin{tabular}{|r|r|l|r|r|}
\hline Entry & Substrate & Ligand & Conv. $^{\text {a }}[\mathbf{\%}]$ & \multicolumn{1}{|c|}{$\mathbf{1}^{\mathbf{a}}$} \\
\hline $\mathbf{1}^{\mathbf{b}}$ & 5 & Xantphos & 33 & $100 / 0$ \\
\hline $\mathbf{2}$ & 6 & $\mathrm{PPh}_{3}$ & 100 & $9 / 91$ \\
\hline $\mathbf{3}^{\mathbf{c}}$ & 6 & Xantphos & 100 & $85 / 15$ \\
\hline $\mathbf{4}$ & 7 & $\mathrm{PPh}_{3}$ & 66 & $50 / 50$ \\
\hline $\mathbf{5}$ & 7 & Xantphos & 54 & $96 / 4$ \\
\hline $\mathbf{6}$ & 8 & $\mathrm{PPh}_{3}$ & 86 & $40 / 60$ \\
\hline $\mathbf{7}$ & 8 & Xantphos & 80 & $92 / 8$ \\
\hline $\mathbf{8}$ & 9 & Xantphos & 61 & $92 / 8$ \\
\hline $\mathbf{9}$ & 10 & PPh & 88 & $40 / 60$ \\
\hline $\mathbf{1 0}$ & 10 & Xantphos & 88 & $92 / 8$ \\
\hline
\end{tabular}

Conditions: $\mathrm{Rh}(\mathrm{acac})(\mathrm{CO})_{2} 1 \mathrm{~mol} \%, \mathrm{PPh}_{3}: 10 \mathrm{~mol} \%$, Xantphos: $5 \mathrm{~mol} \%, \mathrm{CO} / \mathrm{H}_{2}$ (1:1) 40 bar, toluene, $90{ }^{\circ} \mathrm{C}, 24 \mathrm{~h}$. ${ }^{a}$ determined by ${ }^{1} \mathrm{H}$ or ${ }^{19} \mathrm{~F}$ NMR analysis. ${ }^{\circ} \mathrm{CO} / \mathrm{H}_{2}(1: 1) 65$ bar, $120^{\circ} \mathrm{C}$. ${ }^{\mathrm{c}} 0.15 \mathrm{~mol} \%$ [Rh].

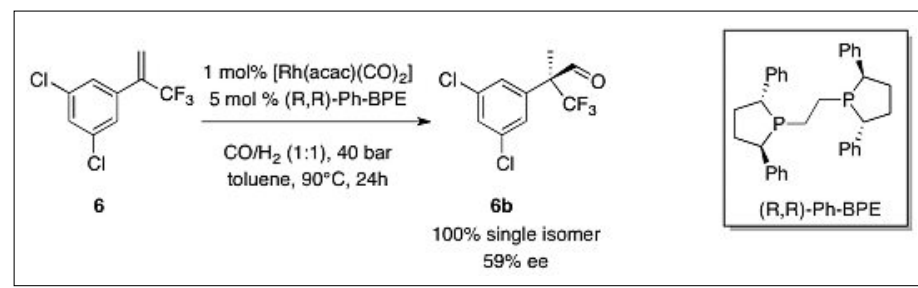

Scheme 12.

Enantioselective hydroformylation of $\alpha-\mathrm{CF}_{3}$-styrene-type substrates.

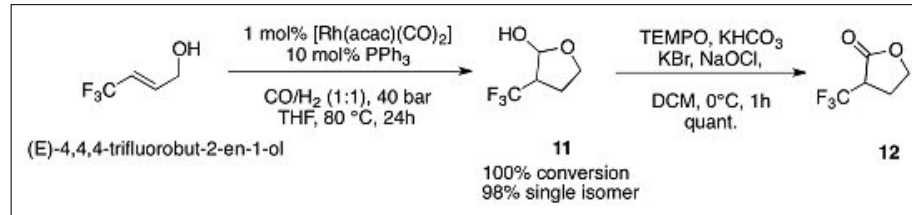

Scheme 13. Regioselective hydroformylation of (E)-4,4,4-trifluorobut2-en-1-ol.

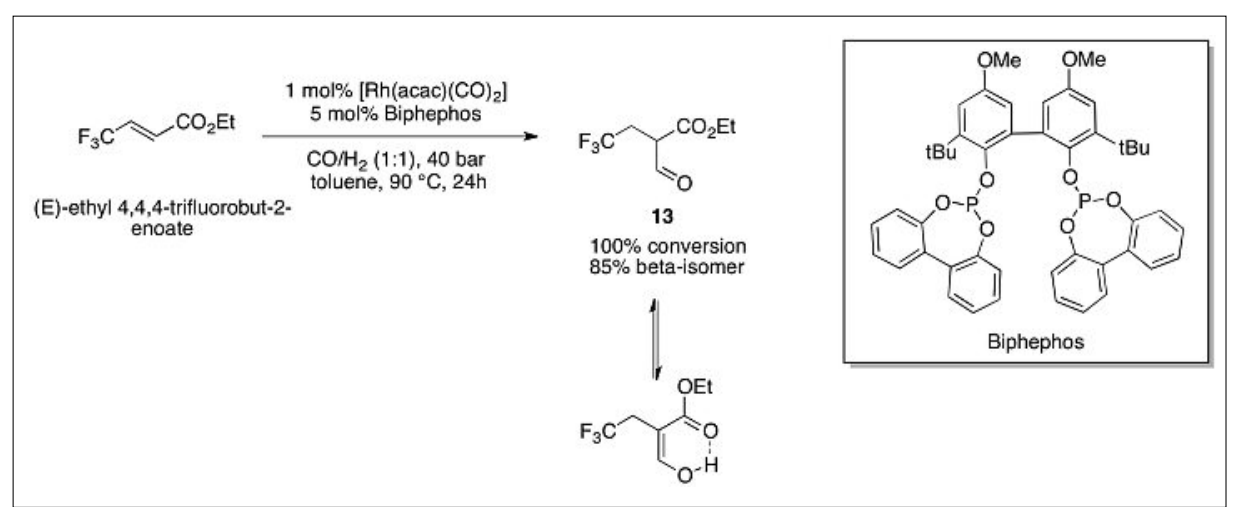

Scheme 14. Regioselective hydroformylation of $(E)$-ethyl-4,4,4-trifluorobut-2-enoate.

\section{Experimental}

All reactions were carried out in oven-dried glassware under an argon atmosphere (Argon 5.0 from Sauerstoffwerke Friedrichshafen) using standard Schlenk techniques. All reagents were purchased from commercial sources and used as received. All solvents were dried and distilled by standard procedures. Chromatographic purification of products was accomplished using Machery-Nagel silica gel $60^{\circledR}$ (230400 mesh). Thin layer chromatography was performed on aluminium plates pre- coated with silica gel (MERCK, 60F254), which were visualized by the quenching of UV fluorescence $(\lambda \max =254 \mathrm{~nm})$, and/ or by $\mathrm{KMnO}_{4}$ solution. Hydroformylation reactions for ligand screening were performed in an Endeavor parallel autoclave with eight reaction vessels from Argonaut Technologies. Hydroformylation reactions were performed in stainless steel autoclaves (autoclave volume: $100 \mathrm{ml}$ ) from Roth using a glass inlet. Gases: carbon monoxide 3.7, hydrogen 4.3 (1:1, MesserGriesheim). Nuclear magnetic resonance (NMR) spectra were acquired on a Bruker 
Avance 400 spectrometer $(400 \mathrm{MHz}$ and 100.6 MHz for ${ }^{1} \mathrm{H}$ and ${ }^{13} \mathrm{C}$ respectively), on a Varian Mercury (300 MHz and 75.5 $\mathrm{MHz}$ for ${ }^{1} \mathrm{H}$ and ${ }^{13} \mathrm{C}$ respectively) and on a Bruker DXR 250 (125 MHz and $235 \mathrm{MHz}$ for ${ }^{1} \mathrm{H}$ and ${ }^{19} \mathrm{~F}$ respectively). All ${ }^{1} \mathrm{H}$ NMR spectra are reported in parts per million (ppm) downfield of TMS and were measured relative to the signals at $7.26 \mathrm{ppm}$ $\left(\mathrm{CDCl}_{3}\right)$ or $7.16 \mathrm{ppm}\left(\mathrm{C}_{6} \mathrm{D}_{6}\right)$. All ${ }^{13} \mathrm{C} \mathrm{NMR}$ spectra were reported in ppm relative to residual $\mathrm{CDCl}_{3}(77.16 \mathrm{ppm})$ or $\mathrm{C}_{6} \mathrm{D}_{6}(128.06$ ppm). All ${ }^{13} \mathrm{C}$ NMR spectra were reported in $\mathrm{ppm}$ relative to the internal standard $\mathrm{C}_{6} \mathrm{~F}_{6}(-164.9 \mathrm{ppm})$. Data for ${ }^{1} \mathrm{H}$ NMR are described as follow: chemical shift (ppm), multiplicity ( $s$, singlet; $d$, doublet; $t$, triplet; $q$, quartet; quint, quintet; $m$, multiplet; $b$, broad signal; pseudo- $q$, pseudo quartet), integration, coupling constant $(\mathrm{Hz})$, attribution. Data for ${ }^{13} \mathrm{C}$ NMR spectra are described in terms of chemical shift (ppm). High resolution mass spectra (HRMS) were obtained on a Finnigan MAT 8200 instrument (EI: $70 \mathrm{eV}$; $\mathrm{CI} / \mathrm{NH}_{3}: 110 \mathrm{eV}$ ). Chiral HPLC was performed on a MERCK HITACHI HPLC apparatus (pump: L-7100, UV detector: D-7400, oven: L-7360; columns: Chiralpak AD-3, OD-3, AD-H and OD-H $25 \mathrm{~cm} 4.6 \mathrm{~cm}$, DAICEL).

\subsection{General Procedure for Hydroformylation of 1,1-Difluoroethene}

Stock solutions of 1,1-difluoroethene were prepared using a particular graduated Schlenk flask and bubbling the fluorinated gas into $10 \mathrm{~mL}$ of distilled toluene or THF at $-90{ }^{\circ} \mathrm{C}$ (bp: 1,1-difluoroethene $\left.=-85^{\circ} \mathrm{C}\right) . \mathrm{C}_{6} \mathrm{~F}_{6}(0.1 \mathrm{M})$ was used as internal standard both for determining the concentration of the gas within the stock solution and the conversion of the substrate after hydroformylation by ${ }^{19} \mathrm{~F}$ NMR technique. The final concentration of the substrate stock solution was between 0.5 and 1.2 molar and remained constant during at least 5 days at low temperature $(-80$ $\left.{ }^{\circ} \mathrm{C}\right)$ storage. Hydroformylation reactions were carried out by using $1 \mathrm{~mL}$ of the substrate stock solution, $\left[\mathrm{Rh}(\mathrm{acac})(\mathrm{CO})_{2}\right](1-2$ $\mathrm{mol} \%)$ as catalyst precursor and a series of 16 different monodentate, bidentate and self-assembling ligands typically used in hydroformylation reactions. Rhodium/carbene systems and different metal complexes such as $\left[\mathrm{Ru}_{3}(\mathrm{CO})_{12}\right],\left[\mathrm{Pt}(\mathrm{COD}) \mathrm{Cl}_{2}\right]$ and $\mathrm{Co}_{2}(\mathrm{CO})_{8}$ were also tested as precatalyst.

The rhodium precatalyst was prepared by mixing the precursor and the modifying ligand in an oven-dried Schlenk flask under Ar. The mixture was transferred into an autoclave under Ar. The autoclave was then cooled to $-90{ }^{\circ} \mathrm{C}$ with a $\mathrm{EtOH} / \mathrm{N}_{2}$ bath and before adding $1 \mathrm{~mL}$ of the stock solution the Ar flux was stopped. The autoclave was pressurized with syngas $\left(\mathrm{CO} / \mathrm{H}_{2}\right.$
$1: 1,20-60$ bar), moved to the aluminium block and heated $\left(25-150{ }^{\circ} \mathrm{C}\right)$ under stirring for $24 \mathrm{~h}$. After reaction the autoclave was cooled to $-90{ }^{\circ} \mathrm{C}$ and then depressurized. A sample of the crude mixture was diluted with $\mathrm{C}_{6} \mathrm{D}_{6}$ in a NMR tube and directly analyzed by ${ }^{19} \mathrm{~F}$ NMR. All the NMR tubes were carried and stored into a dry-ice box before ${ }^{19} \mathrm{~F}$ NMR analysis. In the most cases the hydroformylation was not regioselective resulting in a mixture of linear and branched aldehyde, hydrogenated product and linear hydrate derived from water addition to the linear aldehyde.

3,3-Difluoropropanal (linear aldehyde): ${ }^{19} \mathrm{~F}$ NMR $\left(\mathrm{C}_{6} \mathrm{D}_{6}\right): \delta-118.40(\mathrm{~m}$, $\left.{ }^{4} J_{\mathrm{HF}}=2.9 \mathrm{~Hz},{ }^{3} J_{\mathrm{HF}}=16 \mathrm{~Hz},{ }^{2} J_{\mathrm{HF}}=55 \mathrm{~Hz}\right)$.

1,1-Difluoroethane (hydrogenated prod.): ${ }^{19} \mathrm{~F}$ NMR $\left(\mathrm{C}_{6} \mathrm{D}_{6}\right): \delta-111.09(d q$, $\left.{ }^{3} J_{\mathrm{HF}}=18 \mathrm{~Hz},{ }^{2} J_{\mathrm{HF}}=45 \mathrm{~Hz}\right)$.

2,2-Difluoropropanal (branched aldehyde): ${ }^{19} \mathrm{~F}$ NMR $\left(\mathrm{C}_{6} \mathrm{D}_{6}\right): \delta-105.74(q$, ${ }^{3} \mathrm{~J}_{\mathrm{HF}}=15 \mathrm{~Hz}$ ).

3,3-Difluoropropane-1,1-diol (hydrat$e d):{ }^{19} \mathrm{~F}$ NMR $\left(\mathrm{C}_{6} \mathrm{D}_{6}\right): \delta-103.20(\mathrm{~m})$.

3,3-Difluoropropane-1,1-diol was obtained regioselectively in $10 \%$ conversion ( $\left.\mathrm{TOF}=0.22 \mathrm{~h}^{-1}, \mathrm{TON}=5.23\right)$. Conditions 1,1-difluoroethene/Rh/P(4-OMe-Ph) $50 / 1 / 10$.

\subsection{General Procedure for Hydroformylation of 3,3,3-Trifluoropropene}

The autoclave was closed and purged with argon. In an oven-dried Schlenk-flask a solution of the ligand in freshly dried solvent was prepared under Ar atmosphere. To this solution the metal complex was added and the mixture was stirred for $5 \mathrm{~min} .2$ $\mathrm{mL}$ of TFP were condensed in a flask at $-78{ }^{\circ} \mathrm{C}$ and added to the cooled precatalyst solution $\left(-78^{\circ} \mathrm{C}\right)$ via cooled cannula and Ar flux. The whole reaction mixture was transferred under Ar into the cooled autoclave and pressurized with $\mathrm{CO} / \mathrm{H}_{2}$ gasmixture (1:1) and placed into a pre-heated metal block. At the end of the reaction the crude mixture was analyzed by CG and NMR analysis (internal standard 1,3,5-trimethylbenzene). Distillation at ambient pressure gave the pure aldehydes.

4,4,4-Trifluorobutanal (3-TFMPA): The linear product was obtained in $96 \%$ regioselectivity (bp 94-95 ${ }^{\circ} \mathrm{C}, 1$ atm). Conditions TFP/Pt(COD)Cl/Xantphos/ $\mathrm{SnCl}_{2} 100 / 1 / 2 / 2, \mathrm{CO} / \mathrm{H}_{2}$ (1:1) 96 bar, toluene $(5 \mathrm{M}), 80{ }^{\circ} \mathrm{C}, 48 \mathrm{~h}$.

3,3,3-Trifluoro-2-methylpropanal (2-TFMPA): The branched product was obtained in $95 \%$ regioselectivity (bp $66^{\circ} \mathrm{C}$, $1 \mathrm{~atm})$. Conditions TFP/Rh(acac)(CO)/6DPPon $1000 / 1 / 5, \mathrm{CO} / \mathrm{H}_{2}(1: 1) 20$ bar, toluene $(4 \mathrm{M}), 70{ }^{\circ} \mathrm{C}, 24 \mathrm{~h}$

Analytical data of the aldehydes match those reported previously. ${ }^{[7]}$

Methyl-2-amino-5-(3,3,3-trifluoro- propyl)thiazole-4-carboxylate (3): To 200 mg of 3-TFMPA (1.58 mmol) dissolved in $\mathrm{Et}_{2} \mathrm{O}, \mathrm{NaOMe}(298 \mathrm{mg}, 5.53 \mathrm{mmol})$ and ethyl-dichloroacetate $(220 \mu \mathrm{L}, 1.80$ mmol) were added at $0{ }^{\circ} \mathrm{C}$. The mixture was stirred at $0{ }^{\circ} \mathrm{C}$ and after $2 \mathrm{~h}$ quenched by addition of saturated $\mathrm{NaCl}$. The aqueous phase was extracted with $\mathrm{Et}_{2} \mathrm{O}$, then the combined organic phases were dried over $\mathrm{MgSO}_{4}$ and evaporated. The residue was dissolved in $\mathrm{MeOH}$ and thiourea (120 $\mathrm{mg}, 1.58 \mathrm{mmol}$ ) was added, the reaction mixture was refluxed for $4 \mathrm{~h}$ then stirred at r.t. over night. The product was purified by crystallization from $\mathrm{EtOH} / \mathrm{H}_{2} \mathrm{O}$. Yield $40 \%$. ${ }^{1} \mathrm{H} \mathrm{NMR}\left(\mathrm{CDCl}_{3}\right): \delta 1.89(\mathrm{~m}, 1 \mathrm{H}$, $\left.-\mathrm{CH}_{2} \mathrm{CF}_{3}\right), 2.18\left(m, 1 \mathrm{H},-\mathrm{C}_{2} \mathrm{CF}_{3}\right), 2.39(\mathrm{~m}$, $\left.2 \mathrm{H},-\mathrm{CH}_{2} \mathrm{CH}_{2}-\right), 3.83\left(s, 3 \mathrm{H}_{1},-\mathrm{OCH}_{3}\right), 5.86$ $\left(b, 2 \mathrm{H},-\underline{\mathrm{N}}_{2}\right)$.

Ethyl-2-amino-5-(1,1,1-trifluoropran2-yl)thiazole-4-carboxylate (4): To a solution of ethyl-dichloroacetate $(220 \mu \mathrm{L}$, $1.80 \mathrm{mmol})$ in THF at $-78^{\circ} \mathrm{C}$, LDA (850 $\mu \mathrm{L}, 6.32 \mathrm{mmol}$ ) was added and the mixture stirred at $0{ }^{\circ} \mathrm{C}$ for $15 \mathrm{~min} .200 \mathrm{mg}$ of 2-TFMPA ( $1.58 \mathrm{mmol})$ was then added to the solution and the mixture stirred for 1.5 $\mathrm{h}$ at $0{ }^{\circ} \mathrm{C}$. The reaction was diluted with $\mathrm{Et}_{2} \mathrm{O}$ and washed with $\mathrm{NaCl}$. The organic phase was dried over $\mathrm{MgSO}_{4}$ and evaporated. The residue was dissolved in $\mathrm{MeOH}$ and thiourea (150 mg, $1.89 \mathrm{mmol}$ ) was added, the reaction mixture was refluxed for 2 $\mathrm{h}$ then stirred at r.t. over night. The product was purified by crystallization from EtOH/ $\mathrm{H}_{2} \mathrm{O}$. Yield $30 \%$. ${ }^{1} \mathrm{H} \mathrm{NMR}\left(\mathrm{CDCl}_{3}\right): \delta 1.32$ $\left(d, 3 \mathrm{H}, J=7 \mathrm{~Hz},-\mathrm{CHCH}_{3}\right), 1.35(t, 3 \mathrm{H}, J=$ $\left.7.1 \mathrm{~Hz},-\mathrm{CH}_{2} \underline{\mathrm{CH}}_{3}\right), 4.31\left(m, 1 \mathrm{H},-\underline{\mathrm{HCH}}_{3}\right)$, $4.35\left(q, 2 \mathrm{H}, J=7.1 \mathrm{~Hz},-\mathrm{C}_{2} \mathrm{CH}_{3}\right)$.

\subsection{General Procedure for the Preparation of the $\alpha-\mathrm{CF}_{3}$-Styrene- type Substrate 7, 8, 10 from the Parental Aryl Ketones ${ }^{[21]}$}

In a dry schlenk flask under Ar, to a suspension of KF (227 mg, $3.9 \mathrm{mmol})$ and 18-crown-6 $(13 \mathrm{mg}, 0.05 \mathrm{mmol})$ in dry DMF $(1 \mathrm{~mL}), \mathrm{MsCl}(200 \mu \mathrm{L}, 2.5 \mathrm{mmol})$ was added dropwise under stirring. After $30 \mathrm{~min}$ the aryl ketone $(1 \mathrm{mmol})$ was slowly added and the mixture heated to $110^{\circ} \mathrm{C}$ for $5 \mathrm{~h}$. Workup consisted in portioning the mixture between $\mathrm{H}_{2} \mathrm{O}(2 \mathrm{~mL})$ and $\mathrm{Et}_{2} \mathrm{O}(3 \mathrm{~mL})$, after extraction of the aqueous phase twice with $\mathrm{Et}_{2} \mathrm{O}$, the combined organic phases were washed with saturated $\mathrm{NaHCO}_{3}$ and dried over $\mathrm{MgSO}_{4}$. The product and the unreacted aryl ketone were separated by column chromatography (PE/ $\mathrm{Et}_{2} \mathrm{O} 99: 1,1 \%$ gradient $\left.\mathrm{Et}_{2} \mathrm{O}\right)$.

1-(1,1,1-Trifluoroprop-2-en-2-yl)-4methoxybenzene (7): $62 \%$ yield $(125 \mathrm{mg}$, $0.62 \mathrm{mmol}$ ) from 2,2,2-trifluo-1-(4-methoxyphenyl)ethanone (200 $\mathrm{mg}, 1 \mathrm{mmol})$. ${ }^{1} \mathrm{H}$ NMR $\left(\mathrm{CDD}_{6}\right): \delta 3.23\left(s, 3 \mathrm{H},-\mathrm{OCH}_{3}\right)$, $5.20\left(q, 1 \mathrm{H}, J=1.7 \mathrm{~Hz},=\mathrm{CH}_{2}\right), 5.55(q, 1 \mathrm{H}$, $\left.J=1.3 \mathrm{~Hz},=\mathrm{CH}_{2}\right), 6.64(m, 2 \mathrm{H}, m \mathrm{H}-\mathrm{Ph})$, 
$7.23(\mathrm{~m} d, 2 \mathrm{H}, o \mathrm{H}-\mathrm{Ph}) .{ }^{19} \mathrm{~F}$ NMR $\left(\mathrm{C}_{6} \mathrm{D}_{6}\right)$ : $\delta-64.38(s)$. MS-CI (m/z): [M] 202.1, $[\mathrm{M}+\mathrm{H}] 203.1$.

1-Chloro-4-(1,1,1-trifluoroprop-2-en2-yl)benzene (8): $60 \%$ yield (117 mg, 0.57 $\mathrm{mmol}$ ) from 1-(4-chlorophenyl)-2,2,2-trifluoethanone (208 mg, $1 \mathrm{mmol}) .{ }^{1} \mathrm{H}$ NMR $\left(\mathrm{C}_{6} \mathrm{D}_{6}\right): \delta 5.02\left(q, 1 \mathrm{H}, J=2 \mathrm{~Hz},=\mathrm{CH}_{2}\right), 5.47$ $\left(q, 1 \mathrm{H}, J=1.6 \mathrm{~Hz},=\mathrm{CH}_{2}\right), 6.64(m, 2 \mathrm{H}$, $m \mathrm{H}-\mathrm{Ph}), 6.86(m, 2 \mathrm{H}, o \mathrm{H}-\mathrm{Ph}) .{ }^{13} \mathrm{C} \mathrm{NMR}$ $\left(\mathrm{C}_{6} \mathrm{D}_{6}\right): \delta 120.4,120.8(q, J=6 \mathrm{~Hz}), 128.3$, 128.9, 129.0, 130.3, 131.1, 132.9. ${ }^{19}$ F NMR $\left(\mathrm{C}_{6} \mathrm{D}_{6}\right): \delta-64.52(\mathrm{~s}) . \mathrm{MS}-\mathrm{CI}(\mathrm{m} / \mathrm{z}):[\mathrm{M}+\mathrm{H}]$ 207.1, [M-F] 188.1.

1-Fluoro-3-(1,1,1-trifluoroprop-2-en$2-y l$ )benzene (10): $30 \%$ yield (59 mg, 0.31 mmol) from 1-(4-chlorophenyl)-2,2,2-trifluoethanone (200 mg, $1 \mathrm{mmol}) .{ }^{1} \mathrm{H}$ NMR $\left(\mathrm{C}_{6} \mathrm{D}_{6}\right): \delta 5.04\left(q, 1 \mathrm{H}, J=1.7 \mathrm{~Hz},=\mathrm{CH}_{2}\right)$, $5.47\left(q, 1 \mathrm{H}, J=1.3 \mathrm{~Hz},=\mathrm{CH}_{2}\right), 6.72(\mathrm{~m}, 2 \mathrm{H}$, $\mathrm{Ph}), 6.94(m, 2 \mathrm{H}, \mathrm{Ph})$.

\subsection{General Procedure for Hydroformylation Reactions}

The autoclave was closed and purged with argon. In an oven-dried Schlenk flask a solution of the ligand $(10 \mathrm{~mol} \%$ in case of monodentate ligands, $5 \mathrm{~mol} \%$ in cases of bidentate ligands) in freshly dried toluene or THF $(0.2 \mathrm{M})$ was prepared under Ar atmosphere. To this solution [Rh(acac) $(\mathrm{CO})_{2}$ ] (1.0 mol\%) was added and the mixture was stirred for $5 \mathrm{~min}$. The substrate was then added to the catalytic mixture and stirred for another 2-3 min. The whole reaction mixture was transferred under $\mathrm{Ar}$ into a glass vial containing a stirring bar, then the vial was closed with a septum and equipped with a needle to allow for gas exchange. The glass vial was put into the steel autoclave. The autoclave was sealed and purged three times with 5 bar of the $\mathrm{CO} / \mathrm{H}_{2}$ gas-mixture $(1: 1)$, then pressurized (20-65 bar) and placed into a pre-heated metal block $\left(80-90{ }^{\circ} \mathrm{C}\right)$. The reaction mixture was stirred at the given temperature for $24 \mathrm{~h}$, then evaporated and directly analyzed via ${ }^{1} \mathrm{H}$ or ${ }^{19} \mathrm{~F}$ NMR without further purifications.

4,4,4-Trifluoro-3-phenylbutanal (linear aldehyde): Starting from 1-(1,1,1-trifluoroprop-2-en-2-yl)benzene (5) (33.3 $\mathrm{mg}, 0.2 \mathrm{mmol}$ ): $33 \%$ conversion, the linear product was obtained regioselectively. Conditions: 5/Rh/Xantphos 100/1/5, CO/ $\mathrm{H}_{2}$ (1:1) 65 bar, toluene, $120{ }^{\circ} \mathrm{C} .{ }^{1} \mathrm{H}$ NMR $\left(\mathrm{CDCl}_{3}\right): \delta 3.12\left(\mathrm{~m}, 2 \mathrm{H},-\mathrm{CH}_{2}-\right), 4.03(\mathrm{~m}$, $\left.1 \mathrm{H},-\underline{\mathrm{HCF}}_{3}\right), 7.10-7.24(m, 5 \mathrm{H}, \mathrm{Ph}), 9.69$

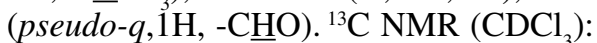
$\delta 43.3,43.5,120.5(q, J=6 \mathrm{~Hz}), 197.4 .{ }^{19} \mathrm{~F}$ NMR $\left(\mathrm{CDCl}_{3}\right): \delta-70.1(d, J=13.2 \mathrm{~Hz})$.

3-(3,5-Dichlorophenyl)-4,4,4trifluorobutanal(linearaldehyde): Starting from 1,3-dichloro-5-(1,1,1-trifluoroprop2-en-2-yl)benzene (6) (4 g, $16.5 \mathrm{mmol})$ : $100 \%$ conversion, the linear product was obtained in $85 \%$ regioselectivity and
$71 \%$ yield after column chromatography (PE/Et $\mathrm{O})$. Conditions: 6/Rh/Xantphos 600/1/7, $\mathrm{CO} / \mathrm{H}_{2}$ (1:1) 40 bar, toluene (1.2 $\mathrm{M}), 90{ }^{\circ} \mathrm{C} .{ }^{1} \mathrm{H}^{2} \mathrm{NMR}\left(\mathrm{C}_{6} \mathrm{D}_{6}\right): \delta 1.90(\mathrm{~m}$, $\left.1 \mathrm{H},-\mathrm{CH}_{2}-\right), 2.11$ (ddd, $1 \mathrm{H}, J=0.68,8.9$, $\left.18.2 \mathrm{~Hz},-\mathrm{CH}_{2}-\right), 3.45(d d, 1 \mathrm{H}, J=4.6,18.7$ $\left.\mathrm{Hz},-\mathrm{CHCF}_{3}\right), 6.87(\mathrm{~m}, 2 \mathrm{H}, \mathrm{oH}-\mathrm{Ph}), 6.94$ $(t, 1 \mathrm{H}, J=1,9 \mathrm{~Hz} p \mathrm{H}-\mathrm{Ph}), 8.71(m, 1 \mathrm{H}$, -C $\underline{\mathrm{HO}}) .{ }^{13} \mathrm{C}$ NMR $\left(\mathrm{C}_{6} \mathrm{D}_{6}\right): \delta 42.3(\mathrm{~m}), 42.7$ $(q, J=29 \mathrm{~Hz}), 127.7,129.1,135.6,137.6$ $(q, J=2 \mathrm{X} \mathrm{Hz}), 195.0 .{ }^{19} \mathrm{~F} \mathrm{NMR}\left(\mathrm{C}_{6} \mathrm{D}_{6}\right): \delta$ $-69.7(d, J=7.05 \mathrm{~Hz})$. MS-CI (m/z): [M-H] $270,272$.

$2-(3,5-$ Dichlorophenyl)-3,3,3trifluoro-2-methylpropanal (branched aldehyde): Starting from 1,3-dichloro5-(1,1,1-trifluoroprop-2-en-2-yl)benzene (6) (144 mg, $0.6 \mathrm{mmol}): 100 \%$ conversion, the branched product was obtained in $91 \%$ regioselectivity and $80 \%$ yield after column chromatography $\left(\mathrm{PE} / \mathrm{Et}_{2} \mathrm{O}\right)$. Conditions: 6/Rh/ $\mathrm{PPh}_{3} 100 / 1 / 10, \mathrm{CO} / \mathrm{H}_{2}$ (1:1) 40 bar, toluene, $90{ }^{\circ} \mathrm{C}$. Under the same condition the up-scaled reaction starting from $1 \mathrm{~g}$ of $6(4.14 \mathrm{mmol})$ gave the branched aldehyde in $75 \%$ regioselectivity and $70 \%$ yield.

The branched product was also obtained regioselectivity and with ee $\%=$ $59 \%$ by using the asymmetric ligand $(R, R)-$ Ph-BPE. Conditions: 6/Rh/( $R, R)-\mathrm{Ph}-\mathrm{BPE}$ $100 / 1 / 5, \mathrm{CO} / \mathrm{H}_{2}$ (1:1) 40 bar, toluene, 90 ${ }^{\circ} \mathrm{C} .{ }^{1} \mathrm{H}$ NMR $\left(\mathrm{C}_{6} \mathrm{D}_{6}\right): \delta 0.95\left(s, 3 \mathrm{H},-\mathrm{CH}_{3}\right)$, $6.95(t, 1 \mathrm{H}, J=1.8 \mathrm{~Hz}, p \mathrm{H}-\mathrm{Ph}), 6.99(\mathrm{~m}$, $2 \mathrm{H}, o \mathrm{H}-\mathrm{Ph}), 8.85(q, 1 \mathrm{H}, J=2.4 \mathrm{~Hz},-\mathrm{C} \underline{\mathrm{HO}})$. ${ }^{13} \mathrm{C} \mathrm{NMR}\left(\mathrm{C}_{6} \mathrm{D}_{6}\right): \delta 14.4(\mathrm{~m}), 58.7(q, J=24$ $\mathrm{Hz}), 127(m), 129.6,132.4,132.5,135.9$ $(m), 136.1,192.1(m) .{ }^{19} \mathrm{~F}$ NMR $\left(\mathrm{C}_{6} \mathrm{D}_{6}\right): \delta$ $-70.6(s)$. MS-CI (m/z): [M-H] 270, 272.

4,4,4-Trifluoro-3-(4-methoxyphenyl) butanal (linear aldehyde): Starting from 1-(1,1,1-trifluoroprop-2-en-2-yl)-4-methoxybenzene (7) (70 $\mathrm{mg}, 0.34 \mathrm{mmol}$ ): $54 \%$ conversion, the linear product was obtained in $96 \%$ regioselectivity. Conditions: 7/Rh/Xantphos 100/1/5, CO/H $(1: 1) 40$ bar, toluene, $90{ }^{\circ} \mathrm{C}$. ${ }^{1} \mathrm{H} \mathrm{NMR}\left(\mathrm{C}_{6} \mathrm{D}_{6}\right): \delta$ $2.49\left(m, 2 \mathrm{H},-\mathrm{CH}_{2}-\right), 3.25\left(\mathrm{~s}, 3 \mathrm{H},-\mathrm{OC} \underline{\mathrm{H}}_{3}\right)$, $3.68\left(m, 1 \mathrm{H},-\underline{\mathrm{HCCF}}_{3}\right), 6.89(\mathrm{~m}, 2 \mathrm{H}, \mathrm{m} \mathrm{H}-$ $\mathrm{Ph}), 7.12(m, 2 \mathrm{H}, o \mathrm{H}-\mathrm{Ph}), 8.95(m, 1 \mathrm{H}$, -Cㅡㅇ). ${ }^{19} \mathrm{~F}$ NMR $\left(\mathrm{C}_{6} \mathrm{D}_{6}\right): \delta-70.2(d, J=$ $11.7 \mathrm{~Hz})$.

3,3,3-Trifluoro-2-(4-methoxyphenyl)2-methylpropanal (branched aldehyde): Starting from 1-(1,1,1-trifluoroprop-2-en2-yl)-4-methoxybenzene (7) $(70 \mathrm{mg}, 0.34$ mmol): $66 \%$ conversion, the branched product was obtained in $50 \%$ regioselectivity. Conditions: $7 / \mathrm{Rh} / \mathrm{PPh}_{3} 100 / 1 / 10, \mathrm{CO} /$ $\mathrm{H}_{2}$ (1:1) 40 bar, toluene, $90{ }^{\circ} \mathrm{C} .{ }^{1} \mathrm{H}$ NMR $\left(\mathrm{C}_{6} \mathrm{D}_{6} 400 \mathrm{MHz}\right): \delta 1.30\left(s, 3 \mathrm{H},-\mathrm{CH}_{3}\right), 3.23$ $\left(s, 3 \mathrm{H},-\mathrm{OCH}_{3}\right), 6.99(m, 2 \mathrm{H}, m \mathrm{H}-\mathrm{Ph})$, $7.12(m, 2 \mathrm{H}, \stackrel{o}{o} \mathrm{H}-\mathrm{Ph}), 9.19(q, 1 \mathrm{H}, J=2.6$ $\mathrm{Hz},-\mathrm{C} \underline{\mathrm{HO}}) .{ }^{19} \mathrm{~F}$ NMR $\left(\mathrm{C}_{6} \mathrm{D}_{6}\right): \delta-70.2(s)$.

3-(4-Chlorophe nyl)-4, 4, 4trifluorobutanal (linear aldehyde): Starting from 1-chloro-4-(1,1,1-trifluoroprop-2-en-2-yl)benzene (8) (86 mg, 0.2 mmol): $80 \%$ conversion, the linear product was obtained in $92 \%$ regioselectivity. Conditions: 8/Rh/Xantphos 100/1/5, CO/ $\mathrm{H}_{2}$ (1:1) 40 bar, toluene, $90{ }^{\circ} \mathrm{C} .{ }^{1} \mathrm{H}$ NMR $\left(\mathrm{C}_{6} \mathrm{D}_{6}\right): \delta 2.44(d d d, J=1.05,9.1,18.1 \mathrm{~Hz}$, $\left.1 \mathrm{H},-\underline{\mathrm{C}}_{2}-\right), 2.29(d d, J=4.7,18.3 \mathrm{~Hz}, 1 \mathrm{H}$, $\left.-\underline{\mathrm{H}}_{2}\right), 3.57\left(\mathrm{~m}, 1 \mathrm{H},-\mathrm{CHCF}_{3}\right), 6.69(\mathrm{~m}, 2 \mathrm{H}$, $m \mathrm{H}-\mathrm{Ph}), 7.11(m, 2 \mathrm{H}, o \mathrm{H}-\mathrm{Ph}), 8.84(m, 1 \mathrm{H}$, $-\mathrm{C} \underline{\mathrm{HO}})$.

2-(4-Chlorophenyl)-3,3,3-trifluoro2-methylpropanal (branched aldehyde): Starting from 1-chloro-4-(1,1,1-trifluoroprop-2-en-2-yl)benzene (8) (86 mg, 0.2 mmol): $86 \%$ conversion, the branched product was obtained in $60 \%$ regioselectivity. Conditions: 8/Rh/ $\mathrm{PPh}_{3}$ 100/1/10, CO/ $\mathrm{H}_{2}$ (1:1) 40 bar, toluene, $90{ }^{\circ} \mathrm{C} .{ }^{1} \mathrm{H}$ NMR $\left(\mathrm{C}_{6} \mathrm{D}_{6}\right): \delta 1.13\left(s, 3 \mathrm{H},-\mathrm{CH}_{3}\right), 6.70(\mathrm{~m}, 2 \mathrm{H}$, $m \mathrm{H}-\mathrm{Ph}), 6.94(m, 2 \mathrm{H}, o \mathrm{H}-\mathrm{Ph}), 9.04(q, 1 \mathrm{H}$, $J=2.5 \mathrm{~Hz},-\mathrm{CHO})$.

4,4,4-trifluoro-3-(3-(trifluoromethyl) phenyl)butanal (linear aldehyde): Starting from 1-(trifluoromethyl)-3-(1,1,1-trifluoroprop-2-en-2-yl)benzene (9) (100 mg, 0.4 $\mathrm{mmol}$ ): $61 \%$ conversion, the linear product was obtained in $92 \%$ regioselectivity. Conditions: 9/Rh/Xantphos 100/1/5, CO/ $\mathrm{H}_{2}$ (1:1) 40 bar, toluene, $90{ }^{\circ} \mathrm{C} .{ }^{1} \mathrm{H}$ NMR $\left(\mathrm{C}_{6} \mathrm{D}_{6}\right): \delta 2.05(d d d, 1 \mathrm{H}, J=0.69,8.9,18.8$ $\left.\mathrm{Hz},-\underline{\mathrm{H}}_{2}-\right), 2.24(d d, 1 \mathrm{H}, J=4.7,18.5 \mathrm{~Hz}$, $\left.-\mathrm{CH}_{2}\right), 3.62\left(\mathrm{~m}, 1 \mathrm{H},-\mathrm{CHCF}_{3}\right), 6.78$ (pseudo- $t, 1 \mathrm{H}, \mathrm{H}^{5}-\mathrm{Ph}$ ), 7.05 (pseudo-d, $1 \mathrm{H}, \mathrm{H}^{6}-$ $\mathrm{Ph}), 7.19\left(m, 1 \mathrm{H}, \mathrm{H}^{4}-\mathrm{Ph}\right), 7.40\left(s, 1 \mathrm{H}, \mathrm{H}^{2}-\right.$ $\mathrm{Ph}), 8.73(\mathrm{~m}, 1 \mathrm{H},-\mathrm{C} \underline{\mathrm{HO}}) .{ }^{19} \mathrm{~F} \mathrm{NMR}\left(\mathrm{C}_{6} \mathrm{D}_{6}\right)$ : $\delta-69.8\left(d, J=9.4 \mathrm{~Hz},-\mathrm{CHCF}_{3}\right),-62.1(s$, $\left.-\mathrm{Ph}-\mathrm{CF}_{3}\right)$.

3,3,3-trifluoro-2-(3-(trifluoromethyl) phenyl)-2-methylpropanal (branched aldehyde): Starting from 1-(trifluoromethyl)3-(1,1,1-trifluoroprop-2-en-2-yl)benzene (9) $(100 \mathrm{mg}, 0.4 \mathrm{mmol}): 37 \%$ conversion, the branched product was obtained regioselectivity and with $e e=49 \%$ by using the asymmetric ligand $(R, R)-\mathrm{Ph}-\mathrm{BPE}$ Conditions: 9/Rh/(R,R)-Ph-BPE 100/1/5, $\mathrm{CO} / \mathrm{H}_{2}$ (1:1) 40 bar, toluene, $90{ }^{\circ} \mathrm{C} .{ }^{1} \mathrm{H}$ $\operatorname{NMR}\left(\mathrm{C}_{6} \mathrm{D}_{6}\right): \delta 1.07\left(s, 3 \mathrm{H},-\mathrm{CH}_{3}\right), 6.74$ (pseudo-t, $\left.1 \mathrm{H}, \mathrm{H}^{5}-\mathrm{Ph}\right), 6,98$ (pseudo-d, $1 \mathrm{H}$, $\left.\mathrm{H}^{6}-\mathrm{Ph}\right), 7.20\left(m, 1 \mathrm{H}, \mathrm{H}^{4}-\mathrm{Ph}\right), 7.52(s, 1 \mathrm{H}$, $\left.\mathrm{H}^{2}-\mathrm{Ph}\right) 8.95(q, 1 \mathrm{H}, J=4 \mathrm{~Hz},-\mathrm{C} \underline{\mathrm{HO}}) .{ }^{19} \mathrm{~F}$ NMR $\left(\mathrm{C}_{6} \mathrm{D}_{6}\right): \delta-70.01\left(s,-\mathrm{CHCF}_{3}\right),-62.4$ $\left(s,-\mathrm{Ph}-\mathrm{CF}_{3}\right)$.

4,4,4-trifluoro-3-(3-fluorophenyl)butanal (linear aldehyde): Starting from 1-fluoromethyl-3-(1,1,1-trifluoroprop2-en-2-yl)benzene (10) (30 mg, 0.26 mmol): $88 \%$ conversion, the linear product was obtained in $92 \%$ regioselectivity. Conditions: 10/Rh/Xantphos 100/1/5, CO/ $\mathrm{H}_{2}$ (1:1) 40 bar, toluene, $90{ }^{\circ} \mathrm{C}$. ${ }^{1} \mathrm{H}$ NMR $\left(\mathrm{C}_{6} \mathrm{D}_{6}\right): \delta 2.19\left(m, 2 \mathrm{H},-\mathrm{CH}_{2}-\right), 3.60(m$, $\left.1 \mathrm{H},-\mathrm{CHCF}_{3}\right), 6.70-7-15(m, 4 \mathrm{H}, \mathrm{Ph}), 8.80$ $(m, 1 \mathrm{H},-\mathrm{C} \underline{\mathrm{HO}})$.

3,3,3-trifluoro-2-(3-fluorophenyl)2-methylpropanal (branched aldehyde): Starting from 1-fluoromethyl-3-(1,1,1trifluoroprop-2-en-2-yl)benzene (10) (30 
$\mathrm{mg}, 0.26 \mathrm{mmol}): 88 \%$ conversion, the branched product was obtained in $60 \%$ regioselectivity. Conditions: 10/Rh/ $\mathrm{PPh}_{3}$ 100/1/10, CO/H (1:1) 40 bar, toluene, 90 ${ }^{\circ} \mathrm{C} .{ }^{1} \mathrm{H}$ NMR $\left(\mathrm{C}_{6} \mathrm{D}_{6}\right): \delta 1.13\left(s, 3 \mathrm{H},-\mathrm{CH}_{3}\right)$, 6.70-7-15 ( $m, 4 \mathrm{H}, \mathrm{Ph}), 9.04(q, 1 \mathrm{H}, J=3$ $\mathrm{Hz}-\mathrm{CHO})$.

3-(trifluoromethyl)-tetrahtdrifuran-ol (11): Starting from $(E)-4,4,4$-trifluorobut2-en-ol (50 mg, $0.40 \mathrm{mmol}$ ): $100 \%$ conversion, the lactol was obtained regioselectively. Conditions: Substrate/Rh/ $\mathrm{PPh}_{3}$ 100/1/10, CO/H (1:1) 40 bar, THF, $90{ }^{\circ} \mathrm{C}$. ${ }^{1} \mathrm{H}$ NMR $\left(\mathrm{C}_{6} \mathrm{D}_{6}\right): \delta 1.58(\mathrm{~m}, 2 \mathrm{H}$,$\left.\mathrm{CH}_{2} \mathrm{CH}_{2} \mathrm{O}\right), 2.62\left(\mathrm{~m}, 1 \mathrm{H},-\mathrm{CHCF}_{3}\right), 3.03$ $(\mathrm{b}, 1 \mathrm{H},-\mathrm{OH}), 3.60\left(\mathrm{~m}, 2 \mathrm{H},-\mathrm{CH}_{2} \mathrm{CH}_{2} \mathrm{O}\right)$, $5.43(d, 1 \mathrm{H}, J=1.8 \mathrm{~Hz}-\mathrm{CHOH}) .{ }^{13} \mathrm{C}$ NMR $\left(\mathrm{C}_{6} \mathrm{D}_{6}\right): \delta 25.0(q, J=2.1 \mathrm{~Hz}), 51.3(q, J=$ $26.8 \mathrm{~Hz}), 66.6,97.9(q, J=3.7 \mathrm{~Hz}) .{ }^{19} \mathrm{~F}$ $\operatorname{NMR}\left(\mathrm{C}_{6} \mathrm{D}_{6}\right): \delta-72.1(d, J=9.4 \mathrm{~Hz})$.

3-(trifluoromethyl)-3,4,5-trihydrofuran-2-one (12): Without further purification after hydroformylation, the crude lactol 7 was oxidized following the procedure reported in ref. [20]. $86 \%$ yield $(51.8 \mathrm{mg}$, $0.34 \mathrm{mmol})$ over 2 steps. ${ }^{1} \mathrm{H}$ NMR $\left(\mathrm{C}_{6} \mathrm{D}_{6}\right)$ : $\delta 1.26\left(m, 1 \mathrm{H},-\mathrm{CH}_{2} \mathrm{CH}_{2} \mathrm{O}\right), 1.50(\mathrm{~m}, 1 \mathrm{H},-$ $\left.\mathrm{C}_{2} \mathrm{CH}_{2} \mathrm{O}\right), 2.36\left(\mathrm{~m}, 1 \mathrm{H},-\mathrm{CHCF}_{3}\right), 3.14$ (pseudo-q, 1H,- $\left.\mathrm{CH}_{2} \mathrm{CH}_{2} \mathrm{O}\right), 3.37^{3}(\mathrm{~m}, 1 \mathrm{H}$, $\left.-\mathrm{CH}_{2} \mathrm{CH}_{2} \mathrm{O}\right) .{ }^{19} \mathrm{~F}$ NMR $\left(\mathrm{C}_{6} \mathrm{D}_{6}\right): \delta-68.5(d$, $J=11.7 \mathrm{~Hz}$ ).

Ethyl-4,4,4-trifluoro-2-formylbutanoate (13): Starting from $(E)$-ethyl-4,4,4trifluorobut-2-enoate ( $30 \mathrm{mg}, 0.26 \mathrm{mmol}$ ): $100 \%$ conversion, the $\beta$-isomer 9 was obtained in $85 \%$ regioselectivity. Conditions: Substrate/Rh/Biphephos 100/1/5, CO/ $\mathrm{H}_{2}$ (1:1) 40 bar, toluene, $90{ }^{\circ} \mathrm{C}$. Enolic form: ${ }^{1} \mathrm{H}$ NMR $\left(\mathrm{C}_{6} \mathrm{D}_{6}\right): \delta 0.84(t, 3 \mathrm{H}, J=$ $\left.10.7 \mathrm{~Hz}, \mathrm{CH}_{3} \mathrm{CH}_{2} \mathrm{O}-\right), 2.37(q, 2 \mathrm{H}, J=15.7$ $\left.\mathrm{Hz},-\mathrm{CH}_{2} \mathrm{CF}_{3}\right), 3.81(q, 2 \mathrm{H}, J=10.7 \mathrm{~Hz}$, $\left.\mathrm{CH}_{3} \mathrm{CH}_{2} \mathrm{O}-\right), 6.65(d, 1 \mathrm{H}, J=18.7 \mathrm{~Hz}$, ole- finic proton), $12.3(q, 1 \mathrm{H}, J=18.7 \mathrm{~Hz}, \mathrm{OH})$. ${ }^{19} \mathrm{~F}$ NMR $\left(\mathrm{C}_{6} \mathrm{D}_{6}\right): \delta-69.4(t, J=16.2 \mathrm{~Hz})$. Data in agreement with those previously reported in ref. [21].

Received: March 25, 2014

[1] a) R. Berger, G. Resnati, P. Metrangolo, E. Weberd, J. Hulliger, Chem. Soc. Rev. 2011, 40 , 3496; b) P. Jeschke, Chem. Bio. Chem. 2004, 5 , 570 ; c) B. E. Smart, J. Fluor. Chem. 2001, 109, 3; d) W. R. Dolbier Jr., J. Fluor. Chem. 2005, 126, 157; e) C. Isanbor, D. O'Hagan, J. Fluor Chem. 2006, 127, 303; f) K. Müller, C. Faeh, F. Diederich, Science 2007, 1881.

[2] a) T. Furuya1, A. S. Kamlet, T. Ritter, Nature 2011, 473, 470; b) G. Landelle, A. Panossian, S. Pazenok, J.-P. Vors, F. R. Leroux, Beilstein J. Org. Chem. 2013, 9, 2476; c) V. V. Grushin, Acc. Chem. Res. 2010, 43, 160; d) D. A. Watson, M. Su, G. Teverovskiy, Y. Zhang, J. Garcia-Fortanet, T. Kinzel, S. L. Buchwald, Science 2009, 325, 1661; e) Y. Hamashima, K. Yagi, H. Takano, L. Tamas, M. Sodeoka, J. Am. Chem. Soc. 2002, 124, 14530; f) X. Wang, L. Truesdale, J.-Q. Yu, J. Am. Chem. Soc. 2010, 132,3648 .

[3] a) S. Imhof, S. Randl, S. Blechert, Chem. Commun. 2001, 1692; b) G. K. S. Prakash, P. Beier, Angew. Chem. Int. Ed. 2006, 45, 2172; c) K. Mikami, Y. Itoh, M. Yamanaka, Chem. Rev. 2004, 104, 1; d) M. Engman, J. S. Diesen, A. Paptchikhine, P. G. Andersson, J. Am. Chem. Soc. 2007, 129, 4536.

[4] a) P. Baumeister, W. Meyer, K. Oertle, G. Seifert, U. Siegrist, H. Steiner, 'Studies in Surface Science and Catalysis'(Heterogeneous Catalysis and Fine Chemicals IV), Elsevier Science B.V., 1997, p. 37; b) P. Baumeister, G. Seifert, H. Steiner, EP584043 (Ciba-Geigy, now Syngenta), year

[5] a) A. Gual, C. Godard, S. Castillón, C. Claver, Tetrahedron: Asymmetry 2010, 21, 1135; b) B. Breit, Top. Curr. Chem. 2007, 279, 139; c) P. W. N. M. van Leeuven, C. Claver, 'Rhodium Catalyzed Hydroformylation' (Catalysis by Metal Complexes), Kluwer Academic Publishers, 2002; d) R. Franke, D. Selent, A Börner, Chem. Rev. 2012, 112, 5675.

[6] For previous review articles see: a) C. Botteghi, G. Del Ponte, M. Marchetti, S. Paganelli, J.
Mol. Catal. 1994, 93, 1; b) I. Ojima, J. Org. Chem. 2013, 78, 6358

[7] I. Ojima, K. Kato, M. Okabe, T. Fuchikami, J. Am. Chem. Soc. 1987, 109, 7714.

[8] H. Bestian, K. Rehn, DE1007771, 1953.

[9] U. Gellrich, D. Himmel, M. Meuwly, B. Breit, Chem. Eur. J. 2013, 19, 16272.

[10] a) K. Nozaki, N. Sakai, T. Nanno, T. Higashijima, S. Mano, T. Horiuchi, H. Takaya, J. Am. Chem. Soc. 1997, 119, 4413; b) K. Nozaki, F. Shibahara, T. Hiyama, Chem. Lett. 2000, 6, 694; c) F. Shibahara, K. Nozaki, T. Hiyama, J. Am. Chem. Soc. 2003, 125, 8555.

[11] a) W. Seiche, A. Schuschowski, B. Breit, $A d v$. Synth. Catal. 2005, 347, 1488; b) B. Breit, W. Seiche, Pure Appl. Chem. 2006, 78, 349.

[12] I. Ojima, K. Kato, K. Nakahashi, T. Fuchikami, M. Fujita, J. Org. Chem. 1989, 54, 4511

[13] S. C. Webster, J. R. Seckl, B. R. Walker, P. Ward, T. D. Pallin, H. J. Dyke, T. R. Perrior, WO2009/74789, 2009.

[14] a) M. J. Dart, W. A. Carroll, A. S. Florancic, J. M. Frost, M. E. Gallagher, T. Kolasa, T. Li, D. W. Nelson, M. V. Patel, S. Peddi, A. Perez-Medrano, K. B. Ryther, K. R. Tietje, WO2007140439, 2007; b) Synthesis of 3 and 4 according to: a) A. Barton, S.P. Breukelman, P. T. Kaye, D. G. Meakins, D. J. Morgan, J. Chem. Soc. Perkin I 1982, 159; b)Y.-M. Cui, Q.-Q. Huang, J. Xu, L.-L. Chen, J.-Y. Li, Q.-Z. Ye, J. Li, F.-J. Nan, Bioorg. Med. Chem. Lett. 2005, 15,3732 .

[15] a) A. I. M. Keuelemans, A. Kwantes, T. van Bavel, Recl. Trav. Chim. Pays-Bas 1948, 67, 298; b) M. L. Clarke, G. J. Roff, Chem. Eur. J. 2006, 12, 7978 .

[16] X. Wang, S. L. Buchwald, J. Org. Chem. 2013, $78,3429$.

[17] a) X. Zhang, F.-L. Qing, Y. Yu, J. Org. Chem. 2000, 65, 7075; b) P.-H.Liang, L.-W. Hsin, C.Y. Cheng, Bioorg. Med. Chem. 2002, 10, 3267.

[18] S. Watanabe, Y. Sakai, M. Takeda, T. Kitazume, T. Yamazaki, J. Fluor. Chem. 1994, 67, 149.

[19] a) A. Hangooly, S. Rozen, Chem. Comm. 2004, 594; b) N. Reineke, N. A. Zaidi, M. Mitra, D. O'Hagan, A. S. Batsanov, J. A. K. Howard, D. Y. Naumov, J. Chem Soc., Perkin Trans. 1 1996, 147 and references therein.

[20] A. J. Laurent, S. Lesniak, Tetrahedron Lett. $\mathbf{1 9 9 2}, 33,3311$.

[21] B. S. Nader, J. A. Cordova, K. E. Reese, C. L. Powell, J. Org. Chem. 1994, 59, 2898. 